\title{
Quantitative immunoelectrophoresis of serum from hospitalized chronic schizophrenic and epileptic patients
}

\author{
H. G. MINCHIN CLARKE, T. FREEMAN ${ }^{1}$, AND W. PRYSE-PHILLIPS \\ From the C.R.C. Laboratory, Whittington Hospital, London
}

SUMMARY Ten serum proteins are measured by quantitative immunoelectrophoresis in 20 chronic schizophrenic and nine epileptic patients. Results from each group are compared with each other and with normal values and significant differences noted. Schizophrenic patients had higher haemopexin levels and epileptic patients had higher $\alpha 2$ group component levels, both compared with normal subjects. Also schizophrenics had higher $\alpha_{1} \mathrm{PG}_{\mathrm{p}}$ and $\alpha_{1} \mathrm{AT}$ levels compared with epileptics.

There exist numerous reports of alterations in biochemical parameters among groups of hospitalized schizophrenic patients. Such parameters have included protein levels determined in various ways and probably among differing types of patients, the diagnosis of schizophrenia being an individual decision which is hard to define and which is not always even described. The conflicting reports of abnormalities have not allowed any firmer hypothesis about the pathogenesis of the schizophrenias than existed before investigations into the protein changes in schizophrenia were begun. The controlled study reported here seeks to take into account some of the variables often ignored by other workers, and thus to place on a firmer basis the minor alterations in serum protein levels which have been described.

\section{MATERIALS AND METHODS}

\section{PATIENT SELECTION}

Two groups of patients were selected on the following criteria.

1. GENERAL All patients were Europeans aged between 20 and 60 years; they had no past history of jaundice or of general organic disease, and showed no evidence of current organic disease. They were fit for occupational or work therapy. Every patient was able to eat the full ward diet; no food supplements were given.

${ }^{1}$ Present address and correspondence: Dr. T. Freeman, Serum Protein Section, Clinical Research Centre, Northwick Park Hospital,
Harrow, Middlesex.
2. DIAGNOSTIC CRITERIA a. Schizophrenia Schizoie phrenic symptoms of the first rank (Schneider, 1959) hidis been detected on admission and could still be elicitodf when examined by one of us during the selection inter 윽 view. Evidence of passivity experiences, primary def sions or thought resonance, withdrawal, sharing, ్ㅏㅇㅡ broadcasting were thus required. Selection was made? initially from patients already diagnosed independengly by other physicians as having paranoid schizophrenga Symptoms of the second rank, including hallucination $\vec{s}$ motor and volitional symptoms, and emotional disturbances with other forms of thought disorder were also recorded in all patients. Those with signs of organic dementia or with affective illness were excluded. Treatment with drugs (apart from monoamine oxidase inhibitors) was not a selection factor.

b. Epilepsy All patients had had grand mal attacks or focal seizures including lapses of consciousness, but not true petit mal. All were exhibiting symptoms and signs of the schizophrenia-like psychoses of epilepsy asdescribed by Slater, Beard, and Glithero (1963). Thus a schizophrenia-like picture, usually without gross affectiveblunting and with or without signs of organic brain disease, was necessary for inclusion in this group.

3 DATA COLlection The patients studied included al those conforming to the selection criteria in a large English mental hospital and in four long-stay wards in as second similar institution. All patients were seen by one of us and information about the past history was recordect from the clinical records onto standard proformas. Theres followed a diagnostic interview in which the clinica? features required for selection were elicited. After selec tion, an afternoon venous blood sample was collectedo without stasis and was separated within four hours of collection. 
4 METHODS Sera were stored at $-20^{\circ} \mathrm{C}$ until analysis by the quantitative immunoelectrophoretic technique described by Laurell (1965) and modified by Clarke and Freeman (1968). Figure 1 shows the type of plate produced by this method; each protein produces a precipitation curve, the area under which is proportional to the quantity of that protein in serum, and inversely proportional to concentration of antibody to that protein. Ten proteins were selected for estimation, and compared with a reference serum. The range for each of these proteins found in a normal European population, using this technique, has been published (Clarke and Freeman, 1968).

Clinical information, together with protein concentration was coded and transferred to IBM 80 column punched cards for statistical treatment.

\section{RESULTS}

PERSONAL DATA In Table 1 the average age, weight, age at onset of disease, duration of illness, duration of in-patient care on admission, drug regimes, and fit frequency are presented. The epileptic patients tended to have had an earlier age of onset (of the epilepsy) than the schizophrenics, and thus the duration of their disease was greater, both as in-patients and altogether. Of the 20 schizophrenic patients, 15 had chronic paranoid psychoses, two were undergoing their first attack of acute schizophrenia (with paranoid ideation), and three had other schizophrenic (hebephrenic, catatonic) illnesses. None of these ever had epileptic fits, but one had had an ECT convulsion the previous week. In the nine epileptic patients no fits had been recorded within the four weeks before interview.

PROTEIN VAlues These are presented in Table 2, all
TABLE 1

PERSONAL DATA ON THE PATIENTS STUDIED

\begin{tabular}{|c|c|c|}
\hline & Schizophrenics & Epileptics \\
\hline Number & 19 & 9 \\
\hline Number (male) & 5 & 7 \\
\hline Mean weight (kg) & $64 \cdot 7$ & $73 \cdot 2$ \\
\hline Average age (yr) & $37 \cdot 4$ & $39 \cdot 4$ \\
\hline (range-yr) & $22-57$ & $29-49$ \\
\hline Average age at onset (yr) & $26 \cdot 8$ & $17 \cdot 1$ \\
\hline Mean duration of illness (yr) & $8 \cdot 8$ & $22 \cdot 3$ \\
\hline $\begin{array}{l}\text { Mean duration of current in-patient } \\
\text { admission (yr) } \\
\text { Mean fit frequency }\end{array}$ & $1 \cdot 6$ & $4 \cdot 9$ \\
\hline$>1 /$ month, patients & Nil & 4 \\
\hline$<1 /$ month, patients & Nil & 5 \\
\hline Drug therapy & \multicolumn{2}{|c|}{ Fatients (no.) } \\
\hline $\begin{array}{l}\text { Phenothiazines } \\
3 \text { months or more }\end{array}$ & 9 & 3 \\
\hline $\begin{array}{l}\text { Phenothiazines } \\
3 \text { months or less }\end{array}$ & 6 & 1 \\
\hline Nil or minor tranquillizer only & 5 & 5 \\
\hline Anti-epileptic drugs & Nil & $\begin{array}{c}8 \\
\text { (phenytoin) } \\
9 \\
\text { (mysoline or } \\
\text { barbiturates) }\end{array}$ \\
\hline
\end{tabular}

figures being given as percentages of a standard normal serum. It will be seen that the schizophrenic patients studied here have significantly higher haemopexin values than the normal series; while the patients with epilepsy had significantly higher $\alpha_{2}$ group component levels than the normal subjects and the schizophrenics. The schizophrenic patients also had higher $\alpha_{1} \mathrm{PGp}$ and $\alpha_{1} \mathrm{AT}$ levels than the epileptics. Apart from these no other characteristics could be defined.

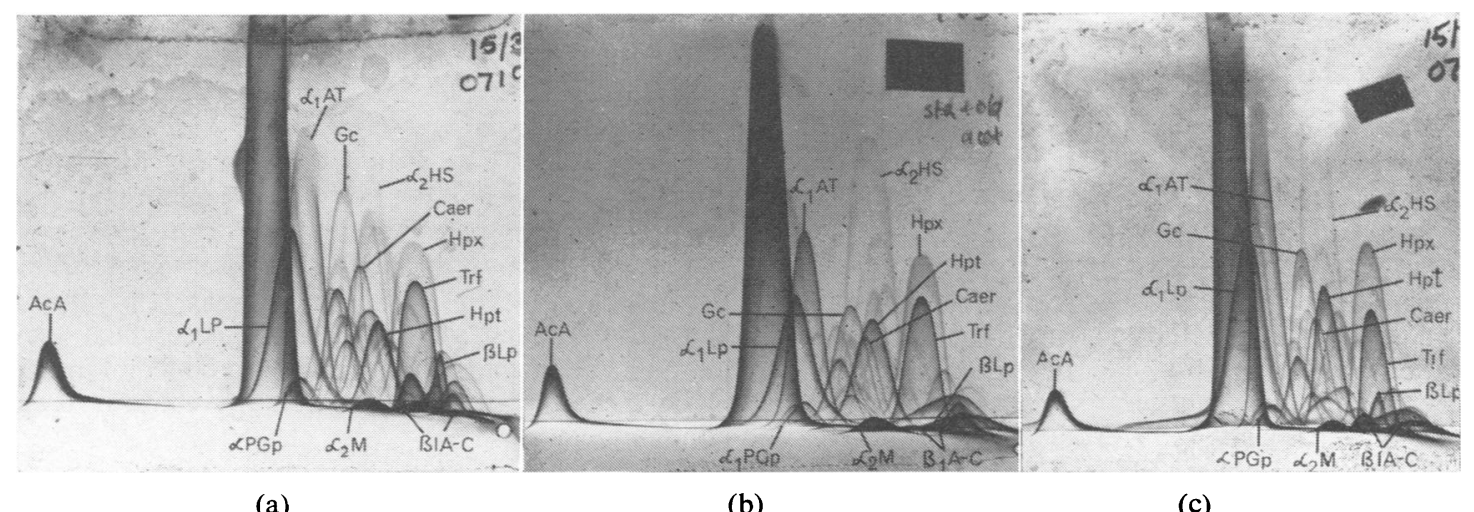

(a)

(b)

(c)

FIG. 1. Characteristic protein patterns in (a) epilepsy: (b) pooled adult serum, and (c) schizophrenia. Only the following proteins were estimated: alpha $a_{1}$ lipoprotein $\left(\alpha_{1} \mathrm{Lp}\right)$, alpha $a_{1}$ easily precipitable glycoprotein $\left(\alpha_{1} \mathrm{PGp}\right)$, alpha $a_{1}$ antitrypsin $\left(\alpha_{1} \mathrm{AT}\right)$, alpha $a_{2}$ group specific component $\left(\alpha_{2} \mathrm{GC}\right)$, alpha $a_{2} \mathrm{HS}\left(\alpha_{2} \mathrm{HS}\right)$, alpha $a_{2}$ macroglobulin $\left(\alpha_{2} \mathrm{M}\right)$, caeruloplasmin $(\mathrm{Caer})$, haptoglobin $(\mathrm{Hpt})$, haemopexin $(\mathrm{Hpx})$, transferrin $(\mathrm{Trf})$, beta lipoprotein $(\beta \mathrm{Lp})$, beta ${ }_{1} \mathrm{~A}_{-} \mathrm{C}\left(\right.$ third $_{\text {component of }}$ complement). 
TABLE 2

MEANS AND STANDARD DEVIATIONS FOR EPILEPTIC AND SCHIZOPHRENIC PATIENTS

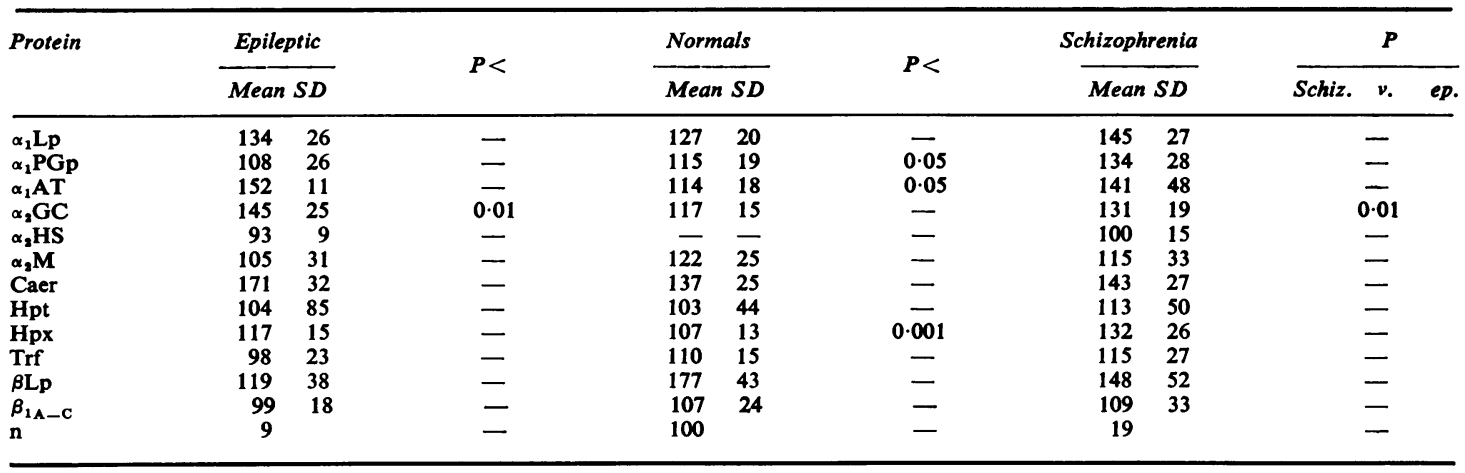

DISCUSSION

Fessell (1961) reviewed the reports of altered serum protein levels in the functional psychoses-that is, non-organic-listing 128 references to relevant work; further studies have subsequently been reported. No protein alteration of diagnostic or prognostic value was found; this may be due to the varying criteria employed in selection of patients, and to differing analytical methods. Alterations in plasma protein concentration may be expected in the presence of undetected liver, kidney, circulatory, neoplastic, or inflammatory disease, and as a result of hormonal drug treatment or a deficit in endogenous hormone production. The influence of race, exercise, and diet is uncertain. Thus it is difficult to compare one previous study with another, or with this one.

The protein alterations reported by previous workers and surveyed by Fessell (1961) and by Seal and Eist (1966) include: (1) increased levels of haptoglobin, orosomucoid, C-reactive protein, rheumatoid factor, combined $\alpha_{1}$ and $\alpha_{2}$ globulins, $\beta$ globulin, and caeruloplasmin; (2) decreased albumin and transferrin; (3) unaltered caeruloplasmin and $\alpha$ and $\beta$ lipoproteins.

Some previous findings have been confirmed by our study. The levels of caeruloplasmin detected were reviewed by Fessell (1961) and by Sandor (1966); both pointed out that initial findings of a raised caeruloplasmin level in schizophrenia (Abood, Gibbs, and Gibbs, 1957; and Scheinberg, Morel, Harris, and Berger, 1957; Martens, Vallbo, and Melander, 1959; and Saunders and Chipkiewicz, 1959) have not been confirmed more recently. We report normal caeruloplasmin levels in schizophrenic patients. Among females, especially those taking oestrogens, caeruloplasmin levels are higher than in males. The only two females among our nine epi- leptic subjects had markedly raised caeruloplasmin levels $(250 \%$ and $172 \%$ reference serum): they were not pregnant, not taking a contraceptive pill, and the changes characteristic of the 'acute phase reaction' were not present.

Abood, Gibbs, and Gibbs (1957) claimed that caeruloplasmin levels were raised within minutes as a response to disturbed behaviour, and among their epileptic patients an abnormally high mean level was detected. Vuyze and Visser (1966) also detected aa raised caeruloplasmin level in serum pooled from $10 \mathrm{Q}$ epileptic patients, while the serum from 10 schizophrenics contained normal amounts. The mean leveto in our nine epileptic patients was higher than that found either among our normal subjects (though not significant, $P=>0.05$ ) or among the schizophrenic patients studied $(P=>0.05)$. We have no evidence that recent epileptic attacks, degree of hydration, dietary or hormonal influences, liver disease, or current emotional crises had any influence in either of our groups.

Unlike Strisower, DeLalla, Gofman, and Strisower (1957) we found lower levels of $\beta$ lipoprotein $(P=>0.05)$ in both the schizophrenics and the epileptics than in the normal subjects. We regard this as an artefact, probably due to storage of serum. Seal and Eist (1966) detected raised haptoglobin levels among 60 male schizophrenics, which they suggest might represent a long-term concomitant of the disease. We were not able to confirm these findings.

The raised $\alpha_{1}$ PGp in schizophrenics $(P=<0.05)$ compared with the normal series, is difficult to explain. $a_{1}$ AT values were also higher $(P=<0.05)$ among the schizophrenics than among the normal series. While the raised haemopexin values $(P=$ $<0.001$ ) in schizophrenia might be evidence of tissue destruction, haptoglobin values were normal and no 
clinical evidence would support such a hypothesis. The schizophrenics' raised haemopexin level was significantly above that of the epileptics, which in turn were similarly, but less markedly, raised above normal. Why a heme-binding protein should be elevated is not clear.

In conclusion, there were raised mean values for $\alpha_{1}$ PGp and $\alpha_{1}$ AT $(P=<0.05)$ and haemopexin $(P=<0.001)$ among our 19 schizophrenics, but the control group of epileptics had normal mean values apart from a high $a$ GC $(P=<0.01)$. We regard these abnormalities as valid, although unexplained, characteristics of our chronic paranoid schizophrenic population.

We would like to express our thanks to Dr. Brice Pitt and his colleagues at Claybury Hospital, and to Dr. Richard Hunter of Friern Barnet Hospital, for allowing us to study their patients. W.P.P. acknowledges with gratitude financial support from the N.W. Metropolitan Regional Hospital Board Research Fund. We would also like to thank Miss Lesley Bissett for skilled technical assistance.

\section{REFERENCES}

Abood, L. G., Gibbs, F. A., and Gibbs, E. (1957). Comparative study of blood ceruloplasmin in schizophrenia and other disorders. Arch. Neurol. Psychiat. (Chic.), 77, 643-645.
Clarke, H. G. M., and Freeman, T. (1968). Quantitative immuno electrophoresis of human serum proteins. Clin. Sci., 35, 403-413.

Fessel, W. J. (1961). Disturbed serum proteins in chronic psychosis: serological, medical and psychiatric correlations. Arch. gen. Psychiat., 4, 154-159.

Laurell, C.-B. (1965). Antigen-antibody crossed electrophoresis. Analyt. Biochem., 10, 358-361.

Martens, S., Valbo, S., and Melander, B. (1959). Studies on the role of ceruloplasmin in schizophrenia. Int. Rev. Neurobiol., 1, 333-342.

Sandor, G. (1966). Serum Proteins in Health and Disease, p. 514. Chapman and Hall: London.

Saunders, J. C., and Chipkiewics, H. (1959). Studies of ceruloplasmin in schizophrenics and normal controls. J. clin. exp. Psycho-pathol., 20, 7-13.

Scheinberg, I. H., Morel, A. G., Harris, R. S., and Berger, A. (1957). Concentration of ceruloplasmin in the plasma of schizophrenic patients. Science, 126, 925-926.

Schneider, K. (1959). Clinical Psychopathology, 5th edn., p. 157. Grune and Stratton: New York.

Seal, U. S., and Eist, H. (1966). Elevation of serum proteinbound carbohydrates and haptoglobin in schizophrenia. Clin. Chem., 12, 709-716.

Slater, E., Beard, A. W., and Glithero, E. (1963). The schizophrenia-like psychoses of epilepsy. Brit. $J$. Psychiat., 109, 95-150.

Strisower, E. H., DeLalla, O., Gofman, J. W., and Strisower, B. (1957). Serum lipoprotein concentrations in a schizophrenic population. Amer. J. Psychiat., 114, 263-265.

Vuyze, G., and Visser, N. H. (1966). Heterogeneity of ceruloplasmin. Protides biol. Fluids, 14, 179. 